\title{
Investigation of the Effect of Protective Gas Composition on Welding Quality in Mag Welding by Tensile Test
}

\author{
Esin Tugba Simsek ${ }^{1 *}$, Ahmet Akkus ${ }^{2}$ \\ 1* Sivas Cumhuriyet University, Hafik Kamer Ornek Vocational School of Higher Education, Department of Transportation Services, Rail Systems Management \\ Program, Sivas, Turkey, (ORCID: 0000-0003-2063-7802), esimsek@cumhuriyet.edu.tr \\ ${ }^{2}$ Sivas Cumhuriyet University, Engineering Faculty, Mechanical Engineering Department, Sivas, Turkey, (ORCID: 0000-0002-6881-9333), aakkus@cumhuriyet.edu.tr
}

(International Conference on Design, Research and Development (RDCONF) 2021 - 15-18 December 2021)

(DOI: 10.31590/ejosat.1040057)

ATIF/REFERENCE: Simsek, E.T. \& Akkus, A. (2021). Investigation of the Effect of Protective Gas Composition on Welding Quality in Mag Welding by Tensile Test. European Journal of Science and Technology, (32), 531-535.

\begin{abstract}
MAG (Metal Active Gas) welding method is widely used in joining structural steels. In this research, S355J2+N structural steel was welded with MAG welding method in the semi-automatic welding mechanism created for the welding process. In order to observe the effect of different shielding gas compositions and different welding speeds used during welding on the welding quality, a total of 27 welded parts were obtained by using 9 gas mixtures and 3 speed values. The samples obtained from the welded parts were examined by performing tensile tests. As a result of this study, it was observed that the tensile strength decreased as the amount of $\mathrm{CO}_{2}$ increased while the $\mathrm{O}_{2}$ was constant in the shielding gas, or as the amount of $\mathrm{O}_{2}$ increased while the $\mathrm{CO}_{2}$ was constant. It has been observed that the welding speed and therefore the number of passes also affect the tensile strength.
\end{abstract}

\section{Mag Kaynağında Koruyucu Gaz Bileşiminin Kaynak Kalitesine Etkisinin Çekme Testi ile İncelenmesi}

$\ddot{\mathbf{O z}}$

Yapı çeliklerinin birleştirilmesinde MAG (Metal Aktif Gaz) kaynak yöntemi yaygın olarak kullanılmaktadır. Bu araştırmada, kaynak işlemi için oluşturulan yarı otomatik kaynak mekanizmasında MAG kaynak yöntemi ile S355J2+N yapı çeliğinin kaynağı yapılmıştır. Kaynak esnasında kullanılan farklı koruyucu gaz bileşimlerinin ve farklı kaynak hızlarının kaynak kalitesine etkisinin gözlemlenmesi amacıyla, 9 adet gaz karışımı ve 3 hız değeri kullanılarak toplamda 27 adet kaynaklı parça elde edilmiştir. Kaynak edilmiş parçalardan elde edilen numunelerin çekme testleri gerçekleştirilerek incelenmiştir. $\mathrm{Bu}$ çalışma sonucunda, koruyucu gaz içindeki $\mathrm{O}_{2}$ sabitken $\mathrm{CO}_{2}$ miktarı arttıkça ya da $\mathrm{CO}_{2}$ sabitken $\mathrm{O}_{2}$ miktarı arttıkça genellikle çekme dayanımında düşüş gözlemlenmiştir. Kaynak hızının ve dolayısıyla paso sayısının da çekme dayanımını etkilediği gözlemlenmiştir.

Anahtar Kelimeler: Mag Kaynağı, S355 Yapı Çeliği, Koruyucu Gaz Karışımı, Otomatik Kaynak.

\footnotetext{
* Corresponding Author: esimsek@cumhuriyet.edu.tr
} 


\section{Introduction}

Gas metal arc welding (MIG-MAG) method; It is used as the most preferred joining method because it is an economical and practical method in machinery manufacturing, transportation sector and mining industry, uninterrupted welding, control of parameters and suitability for automation (Ada et al., 2006; Efe et al., 2019). Structural steel is used in areas such as bridges and railways, ground infrastructures, breakwaters, shipbuilding, oil and gas offshore platforms. Due to the widespread use of MIG/MAG welding method in joining structural steels, researches are also carried out to develop the shielding gases used in this method (Ş1k, 2006).

In order to use the good properties of gases in the most efficient way and to minimize the limitations (Türkkan, 2008), in order to obtain the physical and mechanical properties expected from the post-weld joint, various ratios of gas mixtures are used in accordance with the material being welded (Tülbentçi, 1990; Sacks, 1981; Althouse 1992). The task of the gases is to protect the droplets, the weld pool and the heat affected area from the air and improve the welding arc behavior. Pure $\mathrm{Ar}, \mathrm{Ar}$ and $\mathrm{CO}_{2}$ mixtures, $\mathrm{Ar}$ and $\mathrm{O}_{2}$ mixtures, $\mathrm{Ar}+\mathrm{CO}_{2}+\mathrm{O}_{2}$ and pure $\mathrm{CO}_{2}$ gas are used in shielding gas welding of steels (Pierre, 1987; Raoufi, 1994; Kuna, 1989, Svensson, 1994). Since it is an inert gas, it will not react, thus arc formation and stability will be easy, while $\mathrm{CO}_{2}$ will oxidize the molten arc drop bath and facilitate short-circuit welding at all seam positions and provide a good transition. However, the splash disadvantage of $\mathrm{CO}_{2}$ will be high; on the other hand, it shows that by adding a small amount of $\mathrm{O}_{2}(1 \%$ $5 \%)$ to $\mathrm{CO}_{2}$, the arc flow of the weld form will be improved, spattering will be reduced, deeper penetration and a smoother seam profile will be formed (Türkkan, 2008; Pilarczyk and Szczok, 1994).

(Ada et al., 2006) in their study, performed the welding process of API 5L X65 quality steel materials with cored rutile wire using the MAG welding method and performed the mechanical tests of the welded samples. (Onar, 2020) investigated the effects of different welding currents and speeds on the microhardness of the welded joints in the robotic MAG welding method of XAR 500 steel with a mixture gas containing $86 \% \mathrm{Ar}$, $12 \% \mathrm{CO}_{2}$ and $2 \% \mathrm{O}_{2}$. (Ebrahimnia et al., 2009) investigated the effect of four different shielding gas compositions on the welding properties of St37-2 steel in gas metal arc welding in their study. (Y1lmaz and Tümer, 2013) investigated the effects of shielding gas composition on the microstructure, impact toughness and microhardness distribution of the transition zone between AH36 steel and the weld metal of the joined material. (Liao and Chen, 1999) made comparison and mechanical tests of Gas Metal Arc welding by using five different shielding gas compositions of stainless steel with cored wire and three different compositions with solid wire. In his study, (Ş1k, 2004) welded St37-2 structural steel with MIG/MAG welding method by using three different gas mixtures as $80 \mathrm{Ar}+18 \mathrm{CO}_{2}+2 \mathrm{O}_{2}, \quad 88 \mathrm{Ar}+10 \mathrm{CO}_{2}+2 \mathrm{O}_{2}$ and $93 \mathrm{Ar}+5 \mathrm{CO}_{2}+2 \mathrm{O}_{2}$, and the welded samples were welded performed the bending fatigue tests.

In this study, three speed values were selected in the semiautomatic welding mechanism created for nine different shielding gas mixtures and welding processes, and $\mathrm{S} 355 \mathrm{~J} 2+\mathrm{N}$ steel was joined using MAG welding method, their tensile tests were examined and discussed.

\section{Material and Method}

\subsection{Experimental Materials}

In this study, $\mathrm{S} 355 \mathrm{~J} 2+\mathrm{N}$ structural steel was cut from $150 \times 250 \times 10 \mathrm{~mm}$ plates and $\mathrm{V}$-welds grooves were opened with the help of milling cutter. The chemical content of S355J2+N structural steel is shown in Table 1 in $w t \%$ and its mechanical properties are shown in Table 2.

Table 1. S355J2+N Chemical Composition of Structural Steel (\% by weight)

\begin{tabular}{cccccc}
\hline $\mathrm{C}$ & $\mathrm{Mn}$ & $\mathrm{P}$ & $\mathrm{Si}$ & $\mathrm{Cu}$ & $\mathrm{N}$ \\
\hline 0,1758 & 1,431 & 0,0105 & 0,0092 & 0,0186 & 0,0071 \\
\hline \multicolumn{7}{c}{} \\
$\mathrm{S}$ & $\mathrm{Al}$ & $\mathrm{B}$ & $\mathrm{V}$ & $\mathrm{Ti}$ & $\mathrm{Nb}$ \\
\hline 0,0056 & 0,0365 & 0,0001 & 0,0024 & 0,0011 & 0,0040 \\
\hline
\end{tabular}

\begin{tabular}{ccccc}
\hline $\mathrm{Cr}$ & $\mathrm{Ni}$ & $\mathrm{Mo}$ & $\mathrm{As}$ & $\mathrm{Sn}$ \\
\hline 0,0192 & 0,0295 & 0,0020 & 0,0007 & 0,0015 \\
\hline
\end{tabular}

Table 2. Mechanical Properties of S355J2+N Structural Steel

\begin{tabular}{cccc}
\hline $\begin{array}{c}\text { Yield } \\
\text { Strength } \\
(\mathrm{MPa})\end{array}$ & $\begin{array}{c}\text { Tensile } \\
\text { Strength } \\
(\mathrm{MPa})\end{array}$ & $\begin{array}{c}\% \\
\text { Elongation }\end{array}$ & $\begin{array}{c}\text { Toughness (J) } \\
(-20 \mathrm{C} 0)\end{array}$ \\
\hline 380 & 537 & 27 & 168 \\
\hline
\end{tabular}

In the study, Magmaweld MG 3 brand $1.2 \mathrm{~mm} 15 \mathrm{Kg}$ MAG filler metal with the code AWS/ASME SFA-5.18 ER70S-6 (EN ISO 14341-A G46 4) was used for multi-pass joining of $\mathrm{S} 355 \mathrm{~J} 2+\mathrm{N}$ structural steel. The chemical composition of the welding filler wire is shown in Table 3 and its mechanical properties are shown in Table 4 by weight.

Table 3. Magmaweld MG 3 Welding Wire Chemical Content $(\% w)$

\begin{tabular}{ccc}
\hline \multicolumn{3}{c}{ Elemental \% by weight } \\
\hline $\mathrm{C}$ & $\mathrm{Si}$ & $\mathrm{Mn}$ \\
\hline 0,07 & 0,95 & 1,7 \\
\hline
\end{tabular}

Table 4. Magmaweld MG 3 Welding Wire Mechanical Properties

\begin{tabular}{rrrc}
\hline $\begin{array}{c}\text { Yield } \\
\text { Strength } \\
(\mathrm{MPa})\end{array}$ & $\begin{array}{c}\text { Tensile } \\
\text { Strength } \\
(\mathrm{MPa})\end{array}$ & $\begin{array}{c}\% \\
\text { Elongation }\end{array}$ & $\begin{array}{c}\text { Toughness (J) } \\
(-40 \mathrm{C} 0)\end{array}$ \\
\hline 460 & 570 & 30 & 70 \\
\hline
\end{tabular}


9 pieces of 10-liter special gas mixtures (93\% Ar+5\% $\left.\begin{array}{llllll}\mathrm{CO}_{2}+2 \% & \mathrm{O}_{2}\end{array}\right),\left(\begin{array}{lllll}88 \% & \mathrm{Ar}+10 \% & \mathrm{CO}_{2}+2 \% & \mathrm{O}_{2}\end{array}\right),(83 \% \mathrm{Ar}+15 \%$ $\left.\begin{array}{llllll}\mathrm{CO}_{2}+2 \% & \mathrm{O}_{2}\end{array}\right),\left(\begin{array}{llll}92 \% & \mathrm{Ar}+5 \% & \mathrm{CO}_{2}+3 \% & \mathrm{O}_{2}\end{array}\right),\left(\begin{array}{lll}87 \% & \mathrm{Ar}+10 \%\end{array}\right.$ $\left.\begin{array}{llllll}\mathrm{CO}_{2}+3 \% & \mathrm{O}_{2}\end{array}\right),\left(\begin{array}{lllll}82 \% & \mathrm{Ar}+15 \% & \mathrm{CO}_{2}+3 \% & \mathrm{O}_{2}\end{array}\right), \quad(91 \% \mathrm{Ar}+5 \%$ $\left.\begin{array}{llllll}\mathrm{CO}_{2}+4 \% & \mathrm{O}_{2}\end{array}\right),\left(\begin{array}{llll}86 \% & \mathrm{Ar}+10 \% & \mathrm{CO}_{2}+4 \% & \mathrm{O}_{2}\end{array}\right),(81 \% \mathrm{Ar}+15 \%$ $\mathrm{CO}_{2}+4 \% \mathrm{O}_{2}$ ) were supplied to be used in the MAG Welding method. In the study, Nuriş brand $500 \mathrm{w}$-wrs model, 4 coarse and 10 fine graded direct current (DC) MAG welding machine was used to join the structural steel. Semi-automatic welding mechanism was created to be used in MAG welding process and 3 speed values were selected. These speeds are $10 \mathrm{~cm} / \mathrm{min}, 15$ $\mathrm{cm} / \mathrm{min}$ and $22.5 \mathrm{~cm} / \mathrm{min}$, respectively.

\subsection{Preparation and Joining of Test Samples for Welding}

$\mathrm{S} 355 \mathrm{~J} 2+\mathrm{N}$ structural steel was cut in $150 \times 250 \times 10 \mathrm{~mm}$ dimensions and $30^{\circ} \mathrm{V}$-welds grooves were opened on each piece and they were aligned mutually and made ready for welding. Welding processes were carried out at nine different gas mixtures and at three different speeds for each gas mixture. A copper base was used during welding and the part was fixed to prevent distortions that may occur due to sudden heat input. After the assembly, moisture was removed by applying a preheating of 20$25{ }^{\circ} \mathrm{C}$. After providing suitable conditions, starting from the root pass for speeds of $10 \mathrm{~cm} / \mathrm{min}$ and $15 \mathrm{~cm} / \mathrm{min}$, a hot pass and a cover pass; for the speed of $22.5 \mathrm{~cm} / \mathrm{min}$, it was carried out by MAG welding method as root pass, hot pass and two cover passes. The gas mixture was used with a flow rate of $12 \mathrm{lt} / \mathrm{min}$ and a wire feed speed of $4.9 \mathrm{~m} / \mathrm{min}$. Since the effects of gas will be examined in the welding processes, gas flow rates, amperage, voltage and wire feed rates have been tried to be kept constant.

\subsection{Mechanical Tests Applied to Joints}

Ultrasonic Test (UT) and Magnetic Particle Test (MT) examinations, which are non-destructive test methods, were used to detect the defects of the welds of the test piece joined by the MAG welding method. No surface defects or cracks were detected after the test. Tensile test specimens were extracted using Arion brand IMM-1100 model CNC machine. Tensile test specimens were cut in accordance with ASTM E 8M-01 standard. Tensile test was carried out with Microanalysis brand Universal test machine model device with $100 \mathrm{KN}$ capacity.

\section{Results and Discussion}

\subsection{Tensile Test Results}

In the study, tensile tests were performed on the main material and 54 samples prepared by the standards. The yield stress of the base material, for which the tensile test was carried out, was measured as $320 \mathrm{MPa}$, the breaking stress was $468 \mathrm{MPa}$, and the elongation was $29 \%$. Figure 1 shows the post-test rupture regions of the tensile specimens. Welding speed-tensile strength distribution graph of gas mixtures is given in Figure 2.

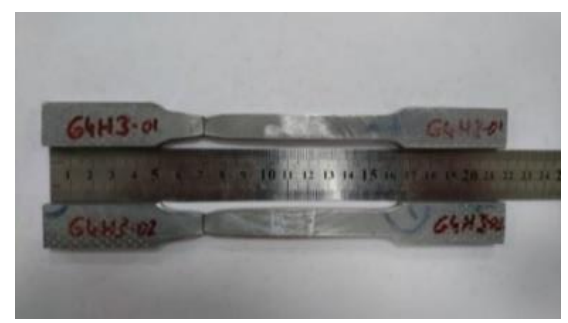

Figure 1. Tensile tested specimen

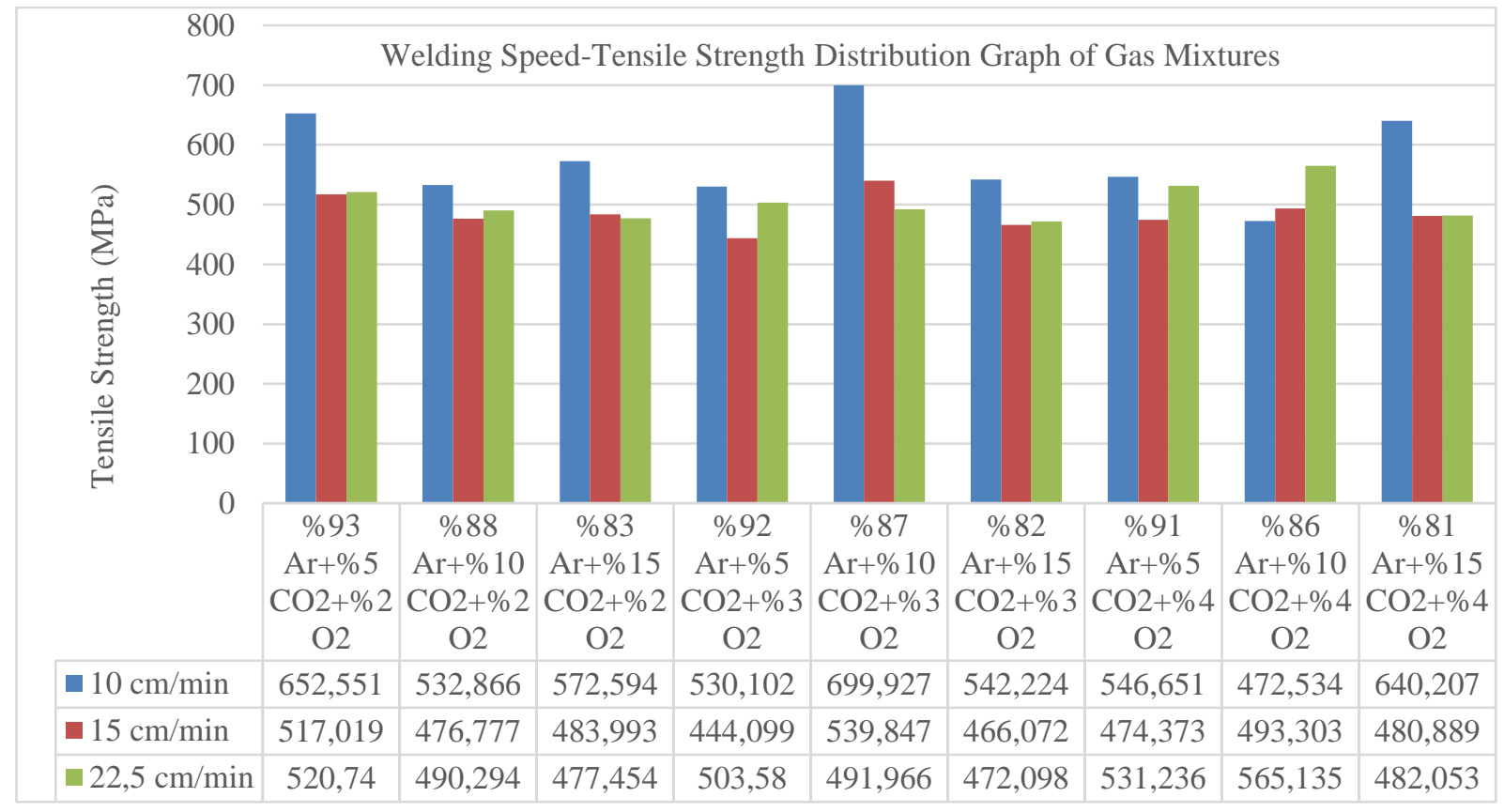

Figure 2. Welding Speed-Tensile Strength Distribution Graph of Gas Mixtures 
In Figure 2, the highest tensile strength was obtained from the welding sample performed at $10 \mathrm{~cm} / \mathrm{min}$ welding speed of $87 \%$ $\mathrm{Ar}+10 \% \mathrm{CO}_{2}+3 \% \mathrm{O}_{2}$ gas mixture. The lowest tensile strength was obtained from the welding sample performed with a gas mixture of $92 \% \mathrm{Ar}+5 \% \mathrm{CO}_{2}+3 \% \mathrm{O}_{2}$ at a welding speed of 15 $\mathrm{cm} / \mathrm{min}$.

In Figure 2, at different speeds, as the amount of $\mathrm{CO}_{2}$ increases while $\mathrm{O}_{2}$ is constant $\left(\left(\mathrm{Ar}+2 \% \mathrm{O}_{2}+\left(5 \% \mathrm{CO}_{2}, 10 \% \mathrm{CO}_{2}\right.\right.\right.$, $\left.\left.15 \% \mathrm{CO}_{2}\right), \mathrm{Ar}+3 \% \mathrm{O}_{2}+\left(5 \% \mathrm{CO}_{2}, 10 \% \mathrm{CO}_{2}, 15 \% \mathrm{CO}_{2}\right)\right), \mathrm{Ar}+4 \%$ $\left.\mathrm{O}_{2}+\left(5 \% \mathrm{CO}_{2}, 10 \% \mathrm{CO}_{2}, 15 \% \mathrm{CO}_{2}\right)\right)$ the tensile strength generally decreases. Since the heat input decreases as the welding speed increases, the tensile strength generally increases first and remains constant after a certain point. However, due to the increase in the number of passes at high speed, the heat input increases and the tensile strength decreases.

In Figure 2, at different speeds, while $\mathrm{CO}_{2}$ is constant, as the amount of $\mathrm{O}_{2}$ increases $\left(\left(\mathrm{Ar}+5 \% \mathrm{CO}_{2}+\left(2 \% \mathrm{O}_{2}, 3 \% \mathrm{O}_{2}, 4 \% \mathrm{O}_{2}\right)\right.\right.$, $\mathrm{Ar}+10 \% \mathrm{CO}_{2}+\left(2 \% \mathrm{O}_{2}, 3 \% \mathrm{O}_{2}, 4 \% \mathrm{O}_{2}\right), \mathrm{Ar}+15 \% \mathrm{CO}_{2}+\left(2 \% \mathrm{O}_{2}\right.$, $\left.3 \% \mathrm{O}_{2}, 4 \% \mathrm{O}_{2}\right)$ ) the tensile strength generally decreases. Since the heat input decreases as the welding speed increases, the tensile strength generally increases first and remains constant after a certain point. However, due to the increase in the number of passes at high speed, the heat input increases and the tensile strength decreases.

In the samples welded with triple mixture gas of $\mathrm{Ar}+\mathrm{CO}_{2}+\mathrm{O}_{2}$, with the increase of $\mathrm{O}_{2}+\mathrm{CO}_{2}$ gases added to Argo after a certain ratio, yield and tensile strengths decrease and \% ductility increases are observed (Ateş, 1996). Adding $\mathrm{CO}_{2}$ to argon increases the arc temperature, $\mathrm{O}_{2}$ affects the weld pool surface tension, making it more uniform, and increasing the weld seam strength. On the contrary, good penetration cannot be achieved with a decrease in the $\mathrm{CO}_{2}$ ratio in the mixture. Gas mixtures containing low $\mathrm{CO}_{2}$ cause argon trapping and nitrogen dissolution in the bath because they cannot provide sufficient heat. This adversely affects the mechanical properties of the weld seam (Gülenç, 1995).

When the tensile test data were examined, the tensile specimens generally did not break from the welded region and HAZ (in some samples, it was observed that there were ruptures from the welded region and HAZ). This result shows that the strength of the applied welding process under mechanical loading exhibits better behavior in the weld metal than in the base material. The resistance of the welded area against deformation during the tensile test causes the \% elongation values of the tensile specimens to be lower than the base material, and therefore rupture occurs in the base material. Parallel to this, the increase in tensile strength is also due to the resistance of the welded region to deformation (Lehto et al., 2014; Kahraman et al., 2005). As a result, it has been concluded that it does not face any problem in use by exceeding the minimum yield and breaking strengths specified in the standards.

\section{Conclusions and Recommendations}

The effect of different shielding gas compositions and different welding speeds on the welding properties of S355J2+N structural steel using MAG welding method was investigated using the tensile test. The results are summarized as follows:

1. While the $\mathrm{O}_{2}$ in the shielding gas is constant, the tensile strength generally decreases as the amount of $\mathrm{CO}_{2}$ increases. Since the heat input decreases as the welding speed increases, the e-ISSN: 2148-2683 tensile strength generally increases first and remains constant after a certain point.

2. While the $\mathrm{CO}_{2}$ in the shielding gas is constant, the tensile strength generally decreases as the amount of $\mathrm{O}_{2}$ increases. Since the heat input decreases as the welding speed increases, the tensile strength generally increases first and remains constant after a certain point.

3. Due to the increase in the number of passes at high speed, the heat input increases and the tensile strength decreases.

4. In the samples welded with triple mixture gas of $\mathrm{Ar}+\mathrm{CO}_{2}+\mathrm{O}_{2}$, a decrease in yield and tensile strengths is observed with the increase of $\mathrm{O}_{2}+\mathrm{CO}_{2}$ gases added to Argon after a certain ratio.

\section{References}

Ada, H., Aksöz, S., Fındık, T., Çetinkaya, C., Bostan, B., \& Candan, İ. (2016). API 5L X65 çeliklerinin mag kaynak yöntemi ile birleştirilmesinde, kaynak işleminin mikroyapı ve mekanik özelliklere etkisinin incelenmesi. Çukurova Üniversitesi Mühendislik-Mimarlik Fakültesi Dergisi, 31(ÖS1), 1-9.

Althouse, A.D., Turnquist, C.H., Bowdich, W.A., Bowdich, K.E. (1992). Modern Welding. South Holland Illinois.

Ateş, H. (1996). MIG-MAG kaynağında kullanılan Argon gazına O2 Ve CO2 ilavesinin kaynak metali tokluğu ve mikroyapısına etkisi. Gazi Üniversitesi, Fen Bilimleri Enstitüsü, Yüksek Lisans Tezi, Ankara.

Ebrahimnia, M., Goodarzi, M., Nouri, M., \& Sheikhi, M. (2009). Study of the effect of shielding gas composition on the mechanical weld properties of steel ST 37-2 in gas metal arc welding. Materials \& Design, 30(9), 3891-3895.

Gülenç, B. (1995). MIG/MAG kaynağında koruyucu gaz karışımının kaynak metalinin mekanik özelliklerine etkisi. Gazi Üniversitesi Fen Bil. Enstitüsü, Doktora Tezi, Ankara.

Kahraman, N., Gülenç, B., Durgutlu, A. (2005). Tozaltı ark kaynağı ile kaynaklanan düşük karbonlu çeliklerde serbest tel uzunluğunun mikroyapı ve mekanik özelliklere olan etkisinin araştırılması. Gazi Üniversitesi Fen Bilimleri Dergisi, 18 (3), 473-480.

Kuna, J. (1989). Effect of shielding gas mixture on the impact toughness of pulsed arc welded joints. Tecnical University of Wroclaw, Poland.

Lehto, P., Remes, H., Saukkonen, T., Hänninen, H., \& Romanoff, J. (2014). Influence of grain size distribution on the HallPetch relationship of welded structural steel. Materials Science and Engineering: A, 592, 28-39.

Liao, M. T., \& Chen, W. J. (1999). A comparison of gas metal arc welding with flux-cored wires and solid wires using shielding gas. The International Journal of Advanced Manufacturing Technology, 15(1), 49-53.

Onar, V. (2020). Robotik MAG Kaynak Metodunda XAR 500 Serisi Çeliklerin Mikrosertliğine Farklı Kaynak Akımlarının ve Hızlarının Etkisi. Düzce Üniversitesi Bilim ve Teknoloji Dergisi, 8(1), 1193-1203.

Pierre, E.R., (1987). Shielding Gases For Welding. Welding Design\&Fabrication, USA.

Pilarczyk, J., \& Szczok, E. (1994). Properties of gas mixtures used in MAG welding. Welding international, 8(11), 845-850.

Raoufi, F. (1994). Parameter optimization in $M I G / M A G$ welding processes (Master's thesis). 
Sacks, J. R. (1981). Welding principles and practices. Macmillan/McGraw-Hill.

Svensson, L. E. (1994). Control Of Microstructures And Properties In Steel Arc Welds. CRC Pres, USA.

Şık, A. (2004). Mig/Mag metodu ile kaynak yapılan yapı çeliği (St37-2) levhaların eğme yorulması gerilmesine çeşitli aktif gazlarının etkisi. Gazi Üniversitesi Endüstriyel Sanatlar Eğitim Fakültesi, 15, 45-57.

Şık, A. (2006). Yapı çeliğinin (St52-3) MIG/MAG kaynağında gaz karışımlarının çekme dayanımı özelliklerine etkisi. Trakya Univ J Sci, 7(1), 9-15.

Tülbentçi, K. (1990). MIG-MAG eriyen elektrod ile gazaltı kaynağı. Gedik Holding.

Türkkan, G. (2008). Koruyucu gaz kaynağında (MIG/MAG) gaz debisinin kaynak nüfuziyeti ve kaynak hızına etkisi (Doctoral dissertation, DEÜ Fen Bilimleri Enstitüsü).

Yılmaz, R., \& Tümer, M. (2013). Microstructural studies and impact toughness of dissimilar weldments between AISI 316 $\mathrm{L}$ and AH36 steels by FCAW. The International Journal of Advanced Manufacturing Technology, 67(5), 1433-1447. 